\title{
UV-Vis Absorbance and Fluorescence Characterization of Pasig River Surface Water Samples Towards the Development of an LED Fluorescence Lidar System
}

\author{
Jumar G. Cadondon ${ }^{\mathrm{a}, \mathrm{c},}$, Edgar A. Vallar ${ }^{\mathrm{a}, \mathrm{b}}$, Lawrence P. Belo ${ }^{\mathrm{d}}$, Aileen H. Orbecido ${ }^{\mathrm{d}}$, \\ Maria Cecilia D. Galvez ${ }^{\mathrm{a}, \mathrm{b}}$ \\ ${ }^{a}$ Environment And RemoTe sensing researcH (EARTH) laboratory, Physics Department, College of Science, De La Salle University Manila \\ 2401 Taft Avenue, Manila 1004, Philippines \\ ${ }^{b}$ Applied Research for Community, Health and Environment Resilience and Sustainability (ARCHERS), Center Natural Sciences and \\ Environmental Research (CENSER), De La Salle University, 2401 Taft Avenue, Malate, Manila, Philippines \\ ${ }^{c}$ Division of Physical Sciences and Mathematics, College of Arts and Sciences, University of the Philippines Visayas-Miagao Campus, \\ Miagao, Iloilo 5023, Philippines \\ ${ }^{d}$ Department of Chemical Engineering, Gokongwei College of Engineering, De La Salle University, 2401 Taft Avenue, Manila 1004, \\ Philippines \\ Corresponding author: ${ }^{*}$ jgcadondon@up.edu.ph
}

\begin{abstract}
The status of water quality in Pasig River was studied using UV-Vis absorbance, 3D excitation-emission matrices (EEMs), fluorescence measurements of dissolved organic matter (DOM), and physicochemical parameters measurements. The study was conducted at seven selected sampling stations in Pasig river from April 2019 to June 2019. It has been years since the government has conducted rehabilitation on the Pasig river and we want to determine its current water quality status with the additional information provided by the UV-Vis absorbance and fluorescence spectroscopy. Several surface water samples were collected using the Pasig River ferry system at (St 1) Lawton Station, (St 4) Valenzuela Station, and (St 7) San Joaquin Station. After computing for the absorbance values at 280-nm, 250-nm/365-nm, 253-nm/203-nm, and 226-400, we have used this method to determine the presence of organic carbon and its aromatic substituents. The results showed low humification degree and aromatic structure and vary from April to June 2019. (St 3) shows higher stability organic molecules containing benzene ring structures. A seasonal variability has been observed from the water quality parameters, which is also present from the fluorescence measurements. DOM sources were measured using fluorescence index (FI), the results showed that all surface water samples were terrestrially derived DOM concentrations. The variance can be attributed to the effluents from the land use types near the sampling stations such as industrial and residential waste. Based on the water quality, absorbance and fluorescence results, the impact of marine waters greatly affects the characterization and production of organic materials.
\end{abstract}

Keywords - Pasig river; water quality; absorbance; excitation-emission matrix; fluorescence spectroscopy.

Manuscript received 13 Aug. 2020; revised 25 Nov. 2020; accepted 1 Dec. 2020. Date of publication 30 Jun. 2021. IJASEIT is licensed under a Creative Commons Attribution-Share Alike 4.0 International License.

\section{INTRODUCTION}

Climate change and human activities have increased the intensity of pollutants and blooms in lakes, reservoirs, and coastal areas. According to World Health Organization, domestic liquid waste contributes $45 \%$ of the pollution load, another $45 \%$ accounts for industrial pollution, and the remaining $10 \%$ accounts for solid waste of the total pollution in Pasig river [1]. It has been considered as one of the biologically dead rivers in the Philippines. It connects two major water bodies, namely, Laguna de Bay, a freshwater system, and Manila Bay, a marine water system. Metro Manila is in the subtropical monsoon area, where dry and wet season are distinct. During the dry season which starts end of November and ends in May, the river flow rate is relatively low and water quality becomes worse during these months accordingly [2]. In January 1999, Pasig river rehabilitation commission (PRRC) was created to ensure that the Pasig river is rehabilitated to its historical condition conducive for the propagation of fishes and other aquatic resources as well as 
for transport, recreation, and tourism [3], [4]. There had been programs and projects on housing and resettlement of informal settlers, riverbank development and flood control, environmental management, advocacy, and tourism, and other PRRC projects [5], [6]. Water quality monitoring stations and data analysis are conducted through Pasig river monitoring systems (PRUMS) project with the initiative of Department of Environment and Natural ResourcesEnvironment Management Bureau (DENR-EMB)-National Capital Region and Central Office, Laguna Lake Development Authority (LLDA), and PRRC which provides coherent water quality report. According to PRRC's quarterly report, some of the sampling stations failed the minimum water quality standards based on the water quality guidelines and general effluent standards of DENR [3]. Tissue analysis on sample fishes caught in the different ferry stations has exceeded the fecal form's permissible limit for good fish [7]. Also, the presence of heavy metals was observed in the suspended sediments [8], fishes [7], and water lilies [9]. With the ongoing river rehabilitation, studies have been conducted on water quality and Physico-chemical measurements [2], [9], [10], and water purification processes [11].

The water quality of inland lakes, reservoirs, and estuaries in Pasig river measured by such factors as biochemical oxygen demand has not improved in a decade. Numerous water quality issues had been connected to dissolved organic matter (DOM). These dissolved organics are commonly found in rivers, lakes, and man-made reservoirs. It consists of complex mixtures of organic molecules such as carbohydrates, proteins, lignin, organic acids, and various humic substances [12]. These components are derived from different sources such as agriculture or sewage or pollutants discharged from petroleum products and industrial effluents [13]. High levels of DOM correspond to poor water quality. Therefore, composition of DOM is important in characterizing water quality and its potential risk to human health and the ecosystem.

Standard methods such as physico-chemical, biological, and bacteriological analyses have high acceptability when water quality is evaluated. However, these analyses require longer time before it can provide an accurate result. This study suggests the use of spectroscopy techniques such as absorbance and excitation-emission fluorescence along with the physico-chemical analyses to evaluate water quality in river systems. With the direct correlation of UV absorption of organic solutes to the content of aromatic compounds using $\mathrm{UV}-\mathrm{Vis}$ spectra, we can estimate the amount of organic carbon in DOM. Also, the degree of humification and its aromatic constituents can be estimated with the UV-Vis absorbance values [14], [16]. Several fluorescence studies have been carried out in river waters with excitation-emission matrices (EEM) [12], [13], [17], [21] and traditional methods [22]. The ability to measure a wide range of excitation and emission wavelengths to graph fluorescence excitationemission matrix has impacted the characterization of DOM. The 3D fluorescence EEMs show significant differences as a function of water samples types and its origins. For the recent years, it is used to characterize and differentiate water masses and provides information on the mixture of coastal and estuarine environments [17], [23], [24]. In this study, UV-Vis absorbance, 3D EEM fluorescence measurements of dissolved organic matter and physico-chemical parameters were conducted on surface water samples collected from Pasig river, specifically at seven ferry stations along the Pasig river ferry system for three months. Several peaks from EEM fluorescence and absorbance values can be used to design a mobile LED-based lidar system for water quality monitoring. This study reiterates the possible use of these methods in measuring DOM's optical properties and to characterize water quality in river systems, which leads to the development of a mobile LED-based lidar system. The water quality monitoring using physico-chemical characteristics with the aid of absorbance and fluorescence spectroscopy measurements delivers information on the current status of Pasig river. This research can improve the status of Pasig river and its tributaries; hence, in-situ water quality monitoring is important.

\section{MATERIALS AND METHODS}

\section{A. Site Description and Surface Water Collection}

1) Sampling site description: Pasig river is about 27 kilometers comprising five cities and municipalities such as Manila, Mandaluyong, Pateros, Makati, Taguig, and Rizal. It has an average depth of 4-5 meters, with water volume of 6.458 million cubic meters, and a current flow of approximately $2.75 \mathrm{kph}$ [2.26]. There are seven sampling stations based on Pasig River Ferry System (Fig. 1). These stations provide information on the surface water quality monitored from April to June 2019. St (1) Lawton Station, St (4) Valenzuela Station, and St (7) are labelled in yellow pins.

The water quality data in this study were obtained from the sampling stations provided in Table 1. It also shows land use data which offers information on the current inhabitants along the riverbanks of Pasig river. The Metro Manila land use 2003 where Pasig river is located provides sixteen variations from very low residential density (VL-1 to VL-3), low residential density (L-1 to L-3), medium residential density (M-1 to M3 ), high residential density ( $\mathrm{H}-1$ to $\mathrm{H}-3$ ), very high residential density (V-1 to V-3), informal settlers (S), commercial \& business, industrial, government \& Quasi-public, education \& cultural, health \& welfare, park \& recreational, religious \& cemetery, transport \&service facility, military, agricultural land, grassland, forestland, water-related and open spaces. 


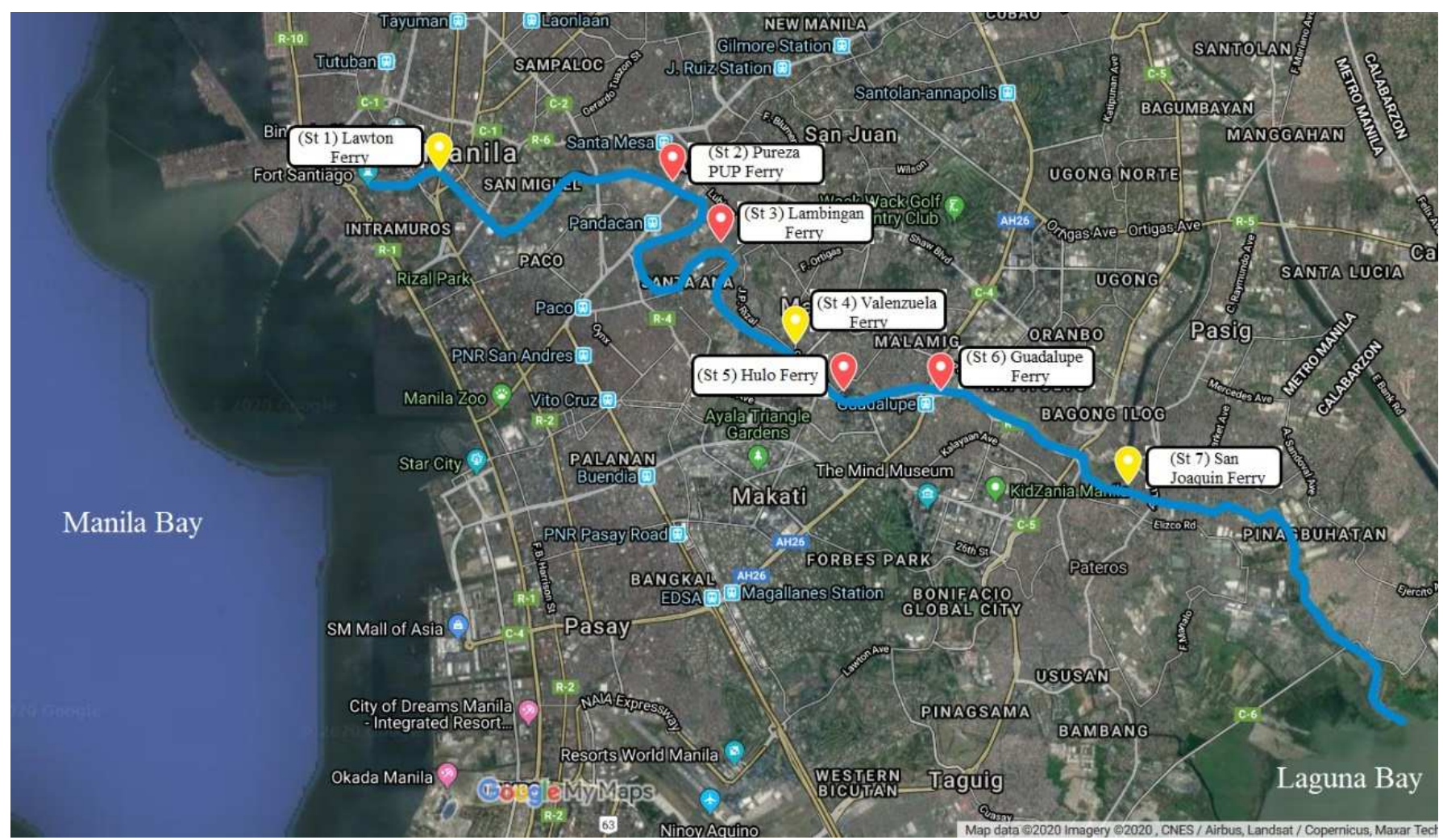

Fig. 1 Pasig River System and the sampling sites [27]

Pasig riverbanks are known for informal settlers and mainly affected by different activities such as industrial, commercial, and predominantly of domestic origin (Table I). According to Pasig River Rehabilitation Commission, there are approximately 800 industries and 250 establishments along the river [28].

TABLE I

SUMMARY OF THE GIS AND LAND USE OF PASIG RIVER SAMPLING STIES [3][27]

\begin{tabular}{|c|c|c|c|}
\hline \multirow{2}{*}{ Station } & \multicolumn{2}{|c|}{ Coordinates } & \multirow{2}{*}{ Land Use } \\
\hline & Latitude & Longitude & \\
\hline $\begin{array}{l}\text { St (1) } \\
\text { Lawton }\end{array}$ & $\begin{array}{r}14^{\circ} 35^{\prime} \\
45.078^{\prime \prime}\end{array}$ & $\begin{array}{r}120^{\circ} 58^{\prime} \\
53.0508^{\prime \prime}\end{array}$ & $\begin{array}{l}\text { Industrial, } \\
\text { Commercial and } \\
\text { Business, Park and } \\
\text { Recreational, } \\
\text { Residential }\end{array}$ \\
\hline $\begin{array}{l}\text { St }(2) \\
\text { Pureza PUP }\end{array}$ & $\begin{array}{r}14^{\circ} 35^{\prime} \\
45.024^{\prime \prime}\end{array}$ & $\begin{array}{r}121^{\circ} 0^{\prime} \\
40.536^{\prime \prime}\end{array}$ & $\begin{array}{l}\text { Cultural, } \\
\text { Government and } \\
\text { Quasi-public, } \\
\text { Industrial }\end{array}$ \\
\hline St (3) & $14^{\circ} 35^{\prime}$ & $121^{\circ} 1^{\prime}$ & Highly Industrial, \\
\hline Lambingan & $16.332^{\prime \prime}$ & $4.008^{\prime \prime}$ & Highly residential \\
\hline St (4) & $14^{\circ} 34^{\prime}$ & $121^{\circ} 1^{\prime}$ & Highly Industrial, \\
\hline Valenzuela & $26.263^{\prime \prime}$ & $33.045^{\prime \prime}$ & Residential \\
\hline St (5) Hulo & $\begin{array}{l}14^{\circ} 34^{\prime} \\
6.348^{\prime \prime}\end{array}$ & $\begin{array}{l}121^{\circ} 2^{\prime} \\
3.336^{\prime \prime}\end{array}$ & $\begin{array}{l}\text { Very Highly } \\
\text { Residential }\end{array}$ \\
\hline $\begin{array}{l}\text { St (6) } \\
\text { Guadalupe }\end{array}$ & $\begin{array}{l}14^{\circ} 34^{\prime} \\
6.348^{\prime \prime}\end{array}$ & $\begin{array}{r}121^{\circ} 2^{\prime} \\
50.316^{\prime \prime}\end{array}$ & $\begin{array}{l}\text { Very Highly } \\
\text { Residential, } \\
\text { Industrial }\end{array}$ \\
\hline $\begin{array}{l}\text { St (7) San } \\
\text { Joaquin }\end{array}$ & $\begin{array}{r}14^{\circ} 33^{\prime} \\
17.0316^{\prime \prime}\end{array}$ & $\begin{array}{c}121^{\circ} 4^{\prime} \\
26.202^{\prime \prime}\end{array}$ & $\begin{array}{l}\text { Highly Residential, } \\
\text { Industrial, } \\
\text { Agricultural Land }\end{array}$ \\
\hline
\end{tabular}

2) Surface Water Collection and Flow rate Measurements: The Pasig River Ferry was used as a mode of transportation starting at the St (1) Lawton Station until St (7) San Joaquin Station. Surface water samples were collected every Friday of the month from April to June 2019 starting from 9:00 AM to 10:30 AM. The whole area is highly residential and large built-up of land-use types are present with the on-going rehabilitation; hence, it is a good sampling collection to investigate the water quality and DOM characteristics in a river system with domestic effluents.

In measuring the river's flow rate, an Arduino-based flow rate sensor with an output pulse of 4.5 for every liter of water passing through it per minute were used. Following the standards on water sampling, the water samples were collected and separated into three containers based on the following tests: (i) the 5-day Biochemical Oxygen Demand $\left(\mathrm{BOD}_{5}\right)$ test, (ii) other physico-chemical parameters, and (iii) absorbance and fluorescence measurements. Only three out of seven sampling stations were monitored for physico-chemical characteristics on surface river water samples collected along Pasig river. The three sampling stations were chosen based on their land use land cover representation and characterized by specific DOM. The sampling stations are as follows:

- St (1) Lawton Station: It represents the confluence of Manila Bay and Pasig River

- St (4) Valenzuela Station: It represents the mid-flow of Pasig River

- St (7) San Joaquin Station: It represents the confluence of Pasig River and Laguna Lake. 


\section{B. Physico-chemical Parameters and Analysis}

DENR has classified Pasig River as Class $\mathrm{C}$ water. This classification is intended for fisheries, agriculture, irrigation, livestock watering, and for recreational activities such as boating, fishing, or any similar activities, i.e., according to the DENR Administrative Order No. 08, Series of 2016 (DAO 2016-08) also known as the "water quality guidelines and general effluent standards of 2016". As shown in Table II, the primary parameters are the required minimum water quality parameters for the said classification.

TABLE II

WATER QUALITY GUIDELINES FOR PRIMARY PARAMETERS [4]

\begin{tabular}{|c|c|c|c|}
\hline \multicolumn{2}{|l|}{ Parameter } & Unit & $\begin{array}{l}\text { "Class C" } \\
\text { Value }\end{array}$ \\
\hline BOD & & $\mathrm{mg} / \mathrm{L}$ & 7 \\
\hline $\begin{array}{l}\text { Dissolved } \\
\text { (Minimum) }\end{array}$ & Oxygen $^{(a)}$ & $\mathrm{mg} / \mathrm{L}$ & 5 \\
\hline pH (Range) & & & $6.5-9.0$ \\
\hline Temperature & & ${ }^{\circ} \mathrm{C}$ & $25-31$ \\
\hline Total Suspen & Solids & $\mathrm{mg} / \mathrm{L}$ & 80 \\
\hline
\end{tabular}

Samples shall be taken from 9:00 AM to 4:00 PM

In-situ water quality parameters such as Temperature, $\mathrm{pH}$, electrical conductivity (EC) and dissolved oxygen (DO) were measured using Hach HQd/intelliCAL Rugged Field. Other parameters, i.e., Biochemical Oxygen Demand (BOD), Total Suspended Solids (TSS), Total Organic Carbon (TOC), and Total Dissolved Solids (TDS), were monitored by grab sampling method and sent to CRL Environmental Corporation for analyses. Gravimetric method was used to measure the TSS and TDS, and Azide Modification Winkler method for BOD measurements. For optimum characterization of water quality, TOC measurements were done with three replicates. The TOC content of water is a useful indicator to determine the degree of pollution.

Field observations based on each sampling station's physical condition were also recorded during the surface water collection. The natural background temperature as determined by EMB shall prevail if the temperature is lower or higher than the water quality guidelines, provided that the maximum increase is only up to $10 \%$ and it will not cause any risk to human health and the environment.

\section{Water Quality Index}

Water quality index (WQI) is a scale that quantifies the state or degree of pollution of surface water parameters collected along Pasig river to standard values. According to [33], the WQI rating reflects the composite influence of different water parameters by comparing water quality to standard set in the targe usage point of view. It states that the closeness of the WQI value to the standard shows better water quality. The Weighted Arithmetic Index method using the quality rating (qi), and relative weight (wi) for each parameter was calculated using eq. (1) and eq. (2), respectively.

$$
\begin{gathered}
q_{1}=\frac{P_{1}}{S_{1}} \times 100 \\
w_{1}=\frac{1}{s_{1}}
\end{gathered}
$$

where $P_{i}$ is the value of the observed parameter, and $S_{i}$ is the set quality. From these equations, the WQI was calculated using eq. (3),

$$
W Q I=\sum_{1}^{n} w_{i} q_{i}
$$

\section{Absorption measurements}

The water samples were immediately transported at the Environment And RemoTe sensing researcH (EARTH) laboratory for the absorbance measurements using the Ocean Optics set-up. Each sample was filtered using $0.47 \mu \mathrm{m}$ pore size filter and prepared in a 10-mm UV-Vis cuvette (BRAND $\mathrm{GMBH}+\mathrm{CO} \mathrm{KG})$. The Xenon lamp (180-2000 nm) is connected using the $600-\mu \mathrm{m}$ fiber cable directly to the cuvette holder for the absorbance spectroscopy set-up. Another 600$\mu \mathrm{m}$ fiber cable is connected from the holder to the spectrometer (Ocean Optics 2000+ XR1-ES). Fig. 2 (a) shows the experimental set-up for the absorbance spectroscopy. Fifty (50) blank samples were also utilized and average to measure the power released by the light. The UV-Vis absorption spectra are obtained between 250-400 nm to measure DOM's humification degree, fulvic and humic substances.

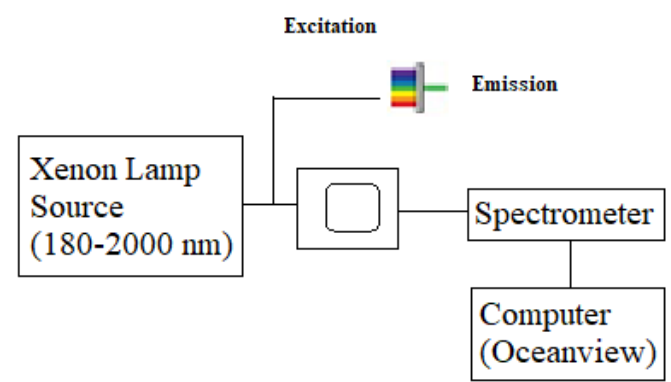

(a)

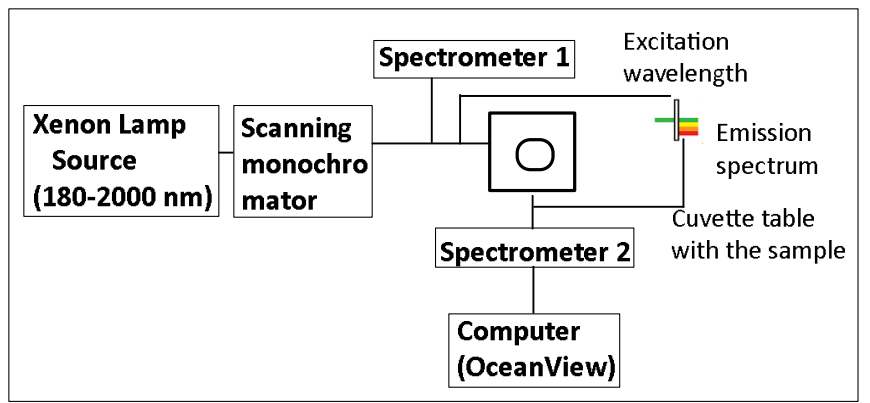

(b)

Fig. 2 The block diagram for (a) absorption spectroscopy, and (b) excitationemission fluorescence spectroscopy

\section{E. Absorption Ratio}

Absorption values of per unit concentration and the absorbances' ratio at specific wavelength include A280, A250/365, A254/436, A340/254 and A253/203 are calculated to determine the humification degree, aromatic structure and distribution of DOM as observed [14]. Table III shows the absorption ratios used to characterize DOM on surface water samples in the Pasig river, an estuarine environment.

TABLE III

SUMMARY OF ABSORPTION VALUES AND RATIOS USED IN CHARACTERIZING DOM IN ESTUARINE ENVIRONMENT [15]-[19]

\begin{tabular}{ll}
\hline $\begin{array}{l}\text { Absorption } \\
\text { value/ratio }\end{array}$ & Target characteristics and relationships \\
\hline A254 & $\begin{array}{l}\text { Organic matter characterization, DOC, and } \\
\text { conductivity correlation } \\
\text { A280 }\end{array}$ \\
$\begin{array}{l}\text { Molecular size, Domestic effluent } \\
\text { characterization, BOD and DOC correlation }\end{array}$
\end{tabular}




\begin{tabular}{ll}
\hline A250/365 & $\begin{array}{l}\text { Molecular weight, negatively correlate with } \\
\text { aromaticity and molecular weight, estuary } \\
\text { environment }\end{array}$ \\
\hline A254/436 & $\begin{array}{l}\text { Probable sources, estimate the relative } \\
\text { composition of autochthonous versus } \\
\text { terrestrial DOM, estuarine environment } \\
\text { (seawater) }\end{array}$ \\
A340/254 It is used to predict DOC/TOC concentration \\
A253/203 & $\begin{array}{l}\text { Correlate positively with trihalomethane } \\
\text { formation potential }\end{array}$ \\
A254 & $\begin{array}{l}\text { Organic matter characterization, DOC, and } \\
\text { conductivity correlation } \\
\text { A280 }\end{array}$ \\
characteriar size, Domestic effluent \\
M250/365 & $\begin{array}{l}\text { Molecular weight, negatively correlate with } \\
\text { aromaticity and molecular weight, estuary } \\
\text { environment }\end{array}$ \\
\hline
\end{tabular}

These absorption ratios are defined as the ratios of the absorption coefficients at two different wavelengths, which are commonly used to determine DOM sources and composition.

\section{F. Fluorescence Measurements}

An Ocean Optics Spectroscopy set-up was also designed for excitation-emission fluorescence measurements. A Xenon lamp source is controlled using scanning monochromator (MonoScan 2000) before it hits the sample. The output source of the MonoScan 2000 is connected to an optical fiber splitter, one cable goes to Ocean optics USB 4000 (Spectrometer 1), and the other cable is connected to the cuvette holder. Ocean optics 2000+ XR1-ES (Spectrometer 2) measured the emission peaks of the sample using Ocean View application (Figure 2 (b)). The excitation wavelength ranges from 250$450 \mathrm{~nm}$ and the emission wavelength ranges from 250- 600 $\mathrm{nm}$. Fluorescence emission spectrum was obtained in every 5 nm-interval of the excitation wavelength.

All fluorescence measurements were conducted at room temperatures $\left(\sim 25^{\circ} \mathrm{C}\right)$. Fifty (50) deionized water samples were average and used as blank samples. The corrected EEM fluorescence data were analyzed. Fluorescence indices and aquatic fluorescence peaks such as Tryptophan-like (Peak T) and humic-like peaks, humic-A (peak A), and humic-C (peak C) were measured. Table IV shows the major fluorescence in aquatic samples.

TABLE IV

SUMMARY OF ABSOPRTION VALUES AND RATIOS USED In CHARACTERIZING DOM In ESTUARINE ENVIRONMENT [15]-[19]

\begin{tabular}{|c|c|c|c|c|}
\hline Index/Component & Parameters & Peak Name & $\begin{array}{l}\text { Probable } \\
\text { Sources* }\end{array}$ & Description \\
\hline Fluorescence Index (HI) & $\begin{array}{l}\text { emission (em) } 470-\mathrm{nm} / \mathrm{em} \text { at } \\
520 \mathrm{~nm} \text { at excitation (ex) } 370 \\
\mathrm{~nm}\end{array}$ & - & - & $\begin{array}{l}\text { Differentiates water samples as } \\
\text { microbial }(\sim 1.8) \text { or terrestrial }(\sim 1.2) \\
\text { origins. }\end{array}$ \\
\hline Biological Index (BIX) & $\begin{array}{l}\text { em 380-nm/em } 420-\mathrm{nm} \text { and } \\
435-\mathrm{nm} \text { at ex 310-nm }\end{array}$ & - & - & $\begin{array}{l}\text { Indicates proportion of newly produced } \\
\text { DOM }\end{array}$ \\
\hline Humification Index (HIX) & $\begin{array}{l}435-480-\mathrm{nm} \text { divided by area } \\
\text { under em } 300-345-\mathrm{nm}+435- \\
480-\mathrm{nm} \text { at ex } 254-\mathrm{nm}\end{array}$ & - & - & $\begin{array}{l}\text { Indicates the presence of humic } \\
\text { substances }\end{array}$ \\
\hline Tryptophan-like & $\begin{array}{l}\text { ex } 270-275-\mathrm{nm} \text { and em } 304- \\
312-\mathrm{nm}\end{array}$ & $\mathrm{T}$ & $\mathrm{T}, \mathrm{A}, \mathrm{M}$ & Amino acids, free or bound in proteins \\
\hline $\begin{array}{l}\text { Ultraviolet A (UV-A) humic- } \\
\text { like }\end{array}$ & $\begin{array}{l}\text { ex } 290-325-\mathrm{nm} \text { and em } 370- \\
430-\mathrm{nm}\end{array}$ & A & $\mathrm{T}, \mathrm{A}, \mathrm{M}$ & $\begin{array}{l}\text { Low molecular weight, associated with } \\
\text { biological activity, present in } \\
\text { wastewater, wetland, and agricultural } \\
\text { environments }\end{array}$ \\
\hline $\begin{array}{l}\text { Ultraviolet C (UV-C) humic- } \\
\text { like }\end{array}$ & $\begin{array}{l}\text { ex } 320-360-\mathrm{nm} \text { and em420- } \\
460-\mathrm{nm}\end{array}$ & $\mathrm{C}$ & $\mathrm{T}$ & $\begin{array}{l}\text { High molecular weight, highly present } \\
\text { in wetlands, and forested environments }\end{array}$ \\
\hline
\end{tabular}

The fluorescence DOM components are designated based on [21] on marine and terrestrial DOM characterization using excitation-emission matrix spectroscopy. One of the basic and most widely used measurement is fluorescence index (FI), which provides information about the source of the samples or degree of degradation of DOM. Fluorescence DOM measurements are commonly calculated using 3D EEM which provides multiple spectra of increasing excitation ranges from UV to blue region.
The EEMs could provide information on the composition, origin, and processing of DOM. These indices use ratios of fluorescence intensity in different regions to provide possible sources and relative contribution of recently produced DOM. DOM characteristics are associated with the range of computed values from BIX and HIX from all sampling stations varies based on their autochthonous components and humic substances, respectively. 


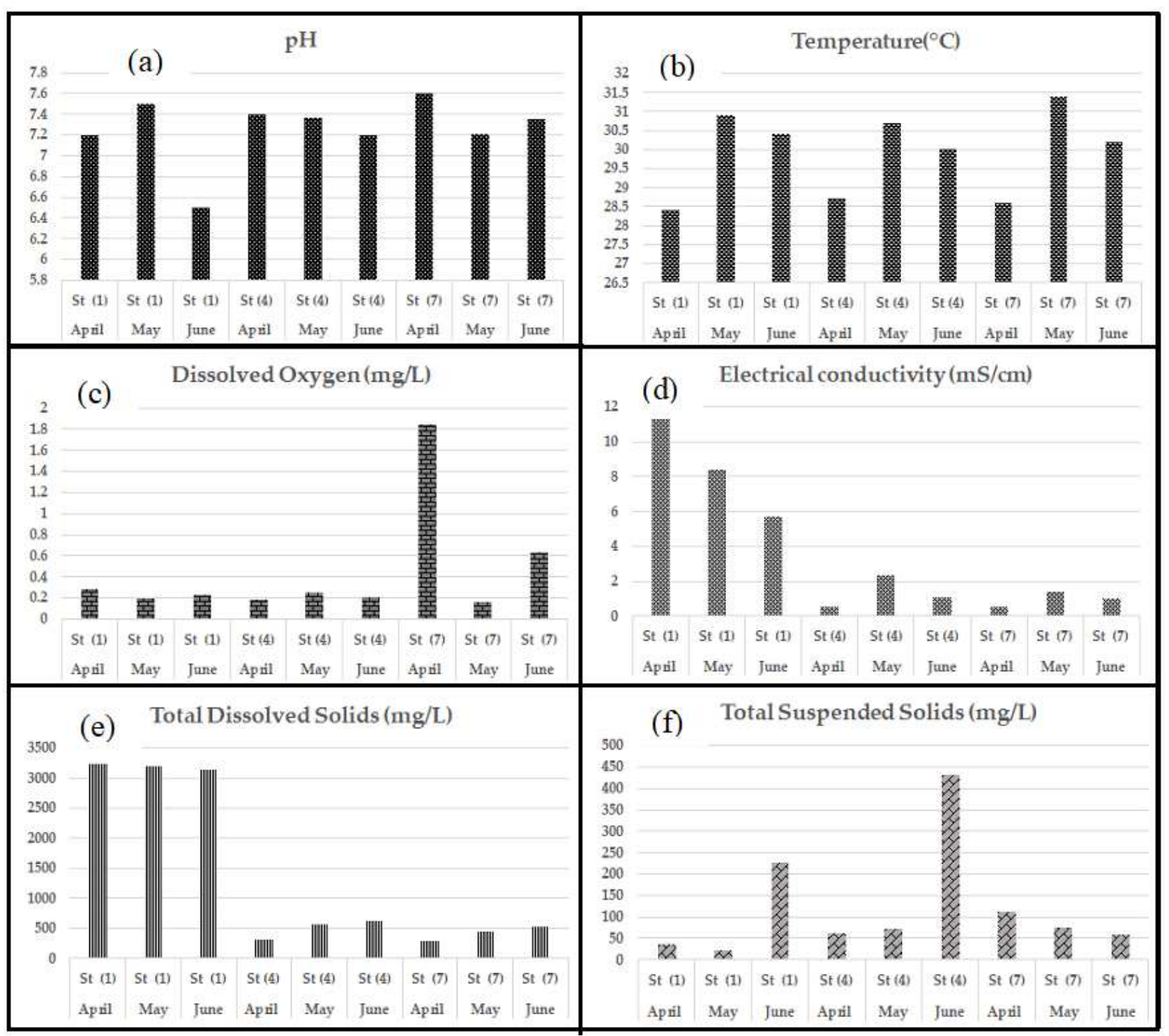

Fig. 3 Trend of physico-chemical characteristics of surface water samples such as (a) pH, (b) temperature, (c) dissolved oxygen, (d) electrical conductivity, (e) total dissolved solids, and (f) total suspended solids along Pasig river

\section{G. Statistical analyses}

Absorbance ratios were used to correlate DOM characteristics such as molecular weight, aromaticity, TOC, and sources. Spectroscopic indices and intensity peaks were correlated to water quality parameters with all months combined. Correlations were conducted in Statistica software and GGally in R. Correlations were considered significant when the correlation coefficients were greater than 0.35 [40].

\section{RESULTS AND DISCUSSION}

In April 2019, the flow rate at St (1) Lawton station is approximately $0.52 \mathrm{~m} / \mathrm{s}$ and gradually decreases to $0.26 \mathrm{~m} / \mathrm{s}$ at St (4) Valenzuela Station. No significant flow was observed at St (7) San Joaquin Station. However, during May 2019, the flow direction varies with upstream flow from Manila Bay to Laguna Lake and an average flow rate of $0.38 \mathrm{~m} / \mathrm{s}$. An average flow rate of $0.31 \mathrm{~m} / \mathrm{s}$ were observed during June 2019 with a flow direction of downstream from Laguna Lake to Manila Bay.

\section{A. Physico-Chemical Properties of Pasig River Water Samples}

The physico-chemical parameters, such as $\mathrm{pH}$, temperature, $\mathrm{EC}, \mathrm{DO}, \mathrm{BOD}_{5}, \mathrm{TSS}, \mathrm{TDS}$, and TOC are shown in Fig. 3. The $\mathrm{pH}$ values are nearly neutral which varies from 6.50 to 7.60 and within the range for Class $C$ type of water. The temperature changes from April to June 2019 ranging from $28.4{ }^{\circ} \mathrm{C}$ to $30.9^{\circ} \mathrm{C}$. DO concentrations on the other hand are significantly low and considered hypoxic since all values are below $2 \mathrm{mg} / \mathrm{L}$. It ranges from $0.16 \mathrm{mg} / \mathrm{L}$ to $1.84 \mathrm{mg} / \mathrm{L}$. The highest DO concentration was observed only at St (7) San Joaquin station during April 2019 which is still below the minimum DO level for Class $\mathrm{C}$ water body. The low DO concentration indicates the presence of high concentrations of biodegradable organic matter in the water. On the other hand, EC values significantly decrease from St (1) Lawton Station to St (7) San Joaquin Station. St (1) Lawton Station has the highest EC values which is due to the confluence of Manila bay, a marine water, and Pasig river, an estuarine system. The same trend is observed in the TDS concentrations. The 
observed TDS levels can be associated with the presence of dissolved salts from Manila Bay.

The TSS concentration varies on each sampling station which ranges from 22 to $432 \mathrm{mg} / \mathrm{L}$. In April 2019, St (1) Lawton Station and St (4) Valenzuela Station are below the minimum TSS concentrations. In May 2019, only St (1) Lawton Station is below the minimum TSS concentrations. However, significant increase in TSS concentrations were observed in June 2019 for St (1) Lawton Station and St (4) Valenzuela Station.
The amount of organic matter present in river samples can be presented with the organic carbon content. Also, BOD5 values quantify the strength of organic matter. Figure 4 shows the amount of organic matter using total organic carbon and biological oxygen demand from April 2019 to June 2019. No detection to low concentration below $3 \mathrm{mg} / \mathrm{L}$ were observed in three sampling stations during the month of April 2019. TOC concentration ranges from 0.11 to $0.99 \mathrm{mg} / \mathrm{L}$ in May 2019. The collected values were very low due to holding time resulting below the detection limit.

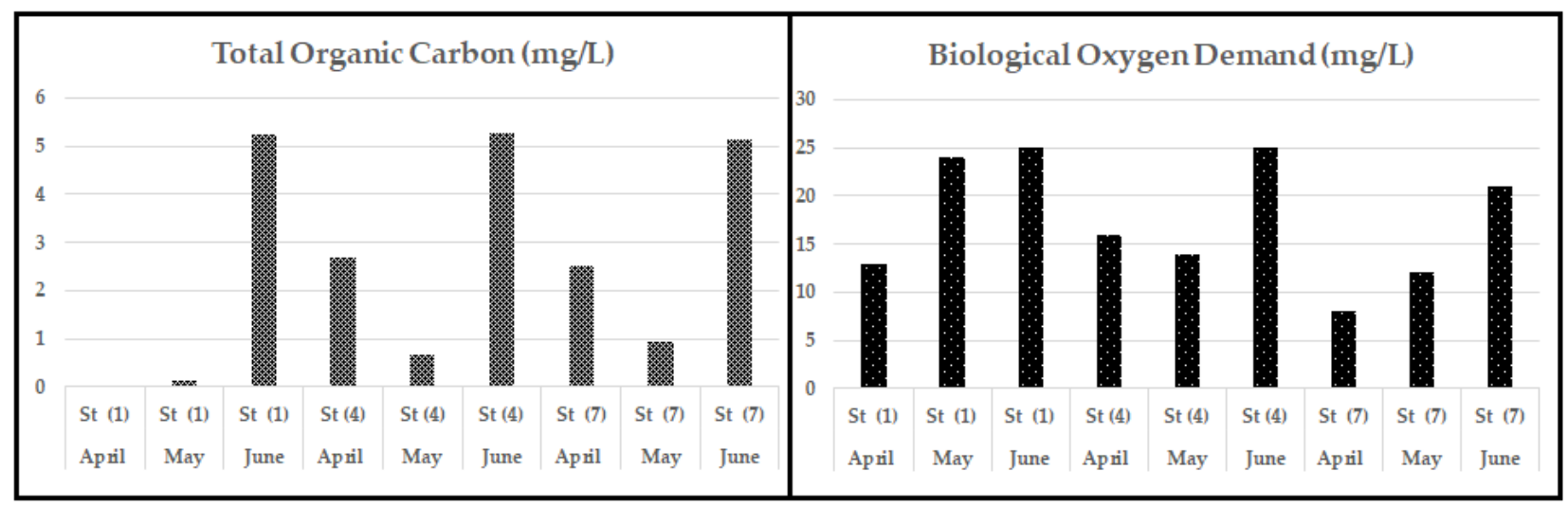

Fig. 4 Trend of organic matter characteristics of surface water samples such as total organic carbon (left) and biological oxygen demand (right) along Pasig river

High concentrations above $5 \mathrm{mg} / \mathrm{L}$ were observed during the month of June 2019. This clearly shows that high production of organic carbon associated with the presence of organic matter is observed in the month of June 2019. BOD concentrations on all sampling stations are higher than the maximum concentration of $7 \mathrm{mg} / \mathrm{L}$ which the DENR sets for Class $\mathrm{C}$ water body. River water is considered clean if it has a $\mathrm{BOD}_{5}$ of $2 \mathrm{mg} / \mathrm{L}$ and below. However, heavily polluted, and severely polluted rivers have $\mathrm{BOD}_{5}$ concentrations of 10-20 $\mathrm{mg} / \mathrm{L}$ and 20 or more $\mathrm{mg} / \mathrm{L}$, respectively [40]. This high $\mathrm{BOD}_{5}$ concentration is one of the reasons for low DO concentration since biodegradation of organic matter consumes the DO in the water. The area's high organic matter is due to the untreated or partially treated sewage discharges from the neighboring cities. The water utilities responsible for treating these wastes are still currently working on increasing the coverage of sewage collection and treatment in the area. Thus, the sewage discharges are currently being mainly treated using septic tanks only.

\section{B. Water Quality Index}

The standard values used for $\mathrm{pH}, \mathrm{BOD}_{5}$, temperature and TSS were obtained from DAO 2016-08. Other measurements such as TOC and BOD were obtained from [2] - [3]. The standard values for the water quality index are dependent on the references used in this study. The $\mathrm{pH}$ standard value ranges from 6.5-9.0 and temperature ranges from 25-31. In this case, the mean value for the $\mathrm{pH}$ and temperature were used as standard value. Also, DO standard value is 5. For the TDS and TSS standard values are1000, and 80, respectively. Lastly, the standard value for $\mathrm{BOD}_{5}$ is 7 . Not all water quality parameters were used in this study due to the standard set value's limitations.
TABLE V

WATER QUALITY INDEX (WQI) PARAMETERS FOR THE STANDARD

\begin{tabular}{lccc}
\hline \multicolumn{1}{c}{ Parameter } & Set Value & $\mathbf{w}_{\mathbf{i}}$ & $\mathbf{w}_{\mathbf{i}} \mathbf{q}_{\mathbf{i}}$ \\
\hline $\mathrm{pH}$ & $7.75(6.5-9.0)$ & 0.129 & 0.387 \\
Temperature & $28(25-31)$ & 0.035 & 0.107 \\
DO & 5 & 0.200 & 0.600 \\
TDS & 1000 & 0.001 & 0.003 \\
TSS & 80 & 0.013 & 0.038 \\
BOD & 7 & 0.143 & 0.429 \\
WQI & & & $\mathbf{2 . 3 1 3}$ \\
\hline
\end{tabular}

The calculated WQI for the standard is 2.313 which indicates good water quality for river waters based on the parameters used. Table VI shows the calculated WQI of the surface water samples collected along three out of seven sampling sites from April 2019 to June 2019. Each sampling station is ranked from highest to lowest for each month. The calculated WQI closest to the standard shows the best water quality condition while the farthest from the standard shows worst water quality condition.

The highest WQI is measured at St (1) Lawton Station with a value of 7.550 while the lowest WQI is St (7) San Joaquin Station with a value of 5.829 for the month of April 2019. The same rank was observed for the month of May 2019. High WQI values observed in St (1) is due to tidal effect from Manila Bay. For the month of June 2019, St (4) Valenzuela Station have the highest WQI value of 12.96 , which is very close to St (1). On the other hand, St (7) has the lowest WQI on the said month. The low WQI values for St (7) can be attributed to the downstream flow from Laguna lake. All WQI values are close to each other and far from the standard value. 
TABLE VI

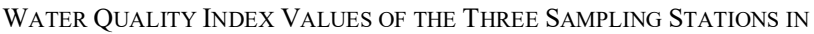
PASIG RIVER FROM APRIL 2019 TO JUNE 2019

\begin{tabular}{lcccccc}
\hline \multicolumn{1}{c}{ Station } & \multicolumn{2}{c}{ April 2019 } & \multicolumn{2}{c}{ May 2019 } & \multicolumn{2}{c}{ June 2019 } \\
\hline & WQI & Rank & WQI & Rank & WQI & Rank \\
\hline Standard & 2.313 & - & 2.313 & - & 2.313 & - \\
St (1) & 7.550 & 3 & 9.033 & 3 & 12.82 & 2 \\
St (4) & 6.057 & 2 & 5.712 & 2 & 12.96 & 3 \\
St (7) & 5.829 & 1 & 5.408 & 1 & 7.672 & 1 \\
\hline
\end{tabular}

\section{UV-Vis Absorption analysis}

UV-Vis absorption is used to approximate molecular sizes, sources, and predictions of DOC from organic matter in rivers. The UV-Vis absorption of the samples is shown in Table VII. Total organic carbon was measured to represent the organic matter content of all samples from all stations. Average values of A254 and A254/436 indicate probable mixture of autochthonous sources of biological activity and allochthonous sources of organic matter. A254 values are lower compared to standard values which indicates that DOM may come from anthropogenic allochthonous sources. These sources are domestic effluents from different land-use types located near the sampling sites. The presence of TOC in effluents has low to zero absorption in the UV region thus diminishing A254 values [42].

TABLE VII

MeAn ABSORBAnCE VALUES AT 280-NM, 253-NM/203-NM, 226-400 NM, AND 250-NM/365-NM OF THE THREE SAMPLING StATIONS FOR APRIL TO MAY 2019

\begin{tabular}{|c|c|c|c|c|c|}
\hline St & $\begin{array}{c}\text { Molecular } \\
\text { Size } \\
\text { A280 }\end{array}$ & THМFP* & $\begin{array}{c}\text { Molecular } \\
\text { weight/Aromaticity } \\
\text { A250/365 }\end{array}$ & $\begin{array}{c}\text { DOM Sources } \\
\text { A254/A436 }\end{array}$ & $\begin{array}{c}\text { DOC } \\
\text { Prediction } \\
\text { A340/A254 }\end{array}$ \\
\hline \multicolumn{6}{|c|}{ APRIL 2019} \\
\hline 1 & 0.231 & 0.211 & 3.234 & 0.893 & 0.278 \\
\hline 2 & 0.220 & 0.206 & 3.221 & 0.790 & 0.460 \\
\hline 3 & 0.168 & 0.148 & 2.788 & 0.457 & 0.371 \\
\hline 4 & 0.144 & 0.115 & 3.112 & 0.567 & 0.443 \\
\hline 5 & 0.122 & 0.195 & 3.105 & 0.678 & 0.502 \\
\hline 6 & 0.130 & 0.268 & 2.996 & 0.420 & 0.430 \\
\hline 7 & 0.335 & 0.293 & 4.967 & 1.020 & 0.564 \\
\hline \multicolumn{6}{|c|}{ MAY 2019} \\
\hline 1 & 0.245 & 0.167 & 3.023 & 0.666 & 0.123 \\
\hline 2 & 0.255 & 0.221 & 3.122 & 0.675 & 0.121 \\
\hline 3 & 0.184 & 0.198 & 3.210 & 0.543 & 0.200 \\
\hline 4 & 0.217 & 0.201 & 3.145 & 0.236 & 0.235 \\
\hline 5 & 0.201 & 0.231 & 3.221 & 0.856 & 0.356 \\
\hline 6 & 0.199 & 0.275 & 3.267 & 0.988 & 0.112 \\
\hline 7 & 0.210 & 0.322 & 3.349 & 1.112 & 0.411 \\
\hline \multicolumn{6}{|c|}{ JUNE 2019} \\
\hline 1 & 0.212 & 0.334 & 3.222 & 0.785 & 1.356 \\
\hline 2 & 0.197 & 0.354 & 3.108 & 0.877 & 1.400 \\
\hline 3 & 0.233 & 0.332 & 3.295 & 0.882 & 1.670 \\
\hline 4 & 0.275 & 0.337 & 3.645 & 0.679 & 1.256 \\
\hline 5 & 0.178 & 0.476 & 3.542 & 0.996 & 1.345 \\
\hline 6 & 0.201 & 0.589 & 3.206 & 1.221 & 1.550 \\
\hline 7 & 0.204 & 0.721 & 3.450 & 1.323 & 1.299 \\
\hline
\end{tabular}

The absorbance at 280-nm was measured to interpret aromatic structures present in the DOM, however, this wavelength does not provide the maximum absorbance but it is normally chosen for phenolic arenes, benzoic acids, aniline derivatives, polyenes, and other aromatic hydrocarbons with two or more rings [14],[21]. It has also been used to measure the humification degree, molecular weight, and aromacity of DOM [22]. Using the UV absorbance at 280-nm, the organic matter's molecular size is highly correlated with its absorption [14]. As seen from Table 5, the aromatic degree changes from 0.144 to 0.335. In April 2019, St (7) San Joaquin Station has higher values compared to the other sampling stations. However, during the three-month long sampling, absorbance values in June 2019 have significantly higher values compared to April and May 2019. It shows that June 2019 sampling period contain more aliphatic chains of substituents aromatic rings while April and May 2019 sampling period may have carbonyl, carboxyl, hydroxyl, and ester substituents. In April 2019, higher absorbance values were measured from St (7) followed by St (1) and St (4), respectively. On the other hand, for May 2019, St (2) has the highest absorbance value while St (1) for the month of June 2019. The absorbance band from 226-nm to 400-nm denotes the variance of organic compounds containing benzene ring in aqueous solution [18]. This provides information on DOM's stability and degradation properties, which more likely states that more organic molecules contain benzene ring structures. St (3) shows consistent results from April to June 2019 , indicating that it has higher stability than other stations. The absorbance ratio at $250-\mathrm{nm}$ and $365-\mathrm{nm}$ provides water carbon origin. In this study, the range varies from 3.023 to 4.967, which represents the origin of fulvic acids [38]-[39]. We can assume through these values the presence of dissolved organic carbon and the presence of fulvic acids. With the UV- 
Vis absorbance values, we can approximate the presence of dissolved organic carbon and its aromatic substituents as observed on the low DO values, and the effluents from industrial, business, and residential near the sampling stations from April to June 2019 [43]. Poor water quality shows a deteriorating humification degree. The poor quality of Pasig river shows the effect of effluents from the different DOM sources. On the other hand, St (3) is predominantly residential and agricultural land in the southern region where water qualities are much better.

\section{St (1) Lawton Station}
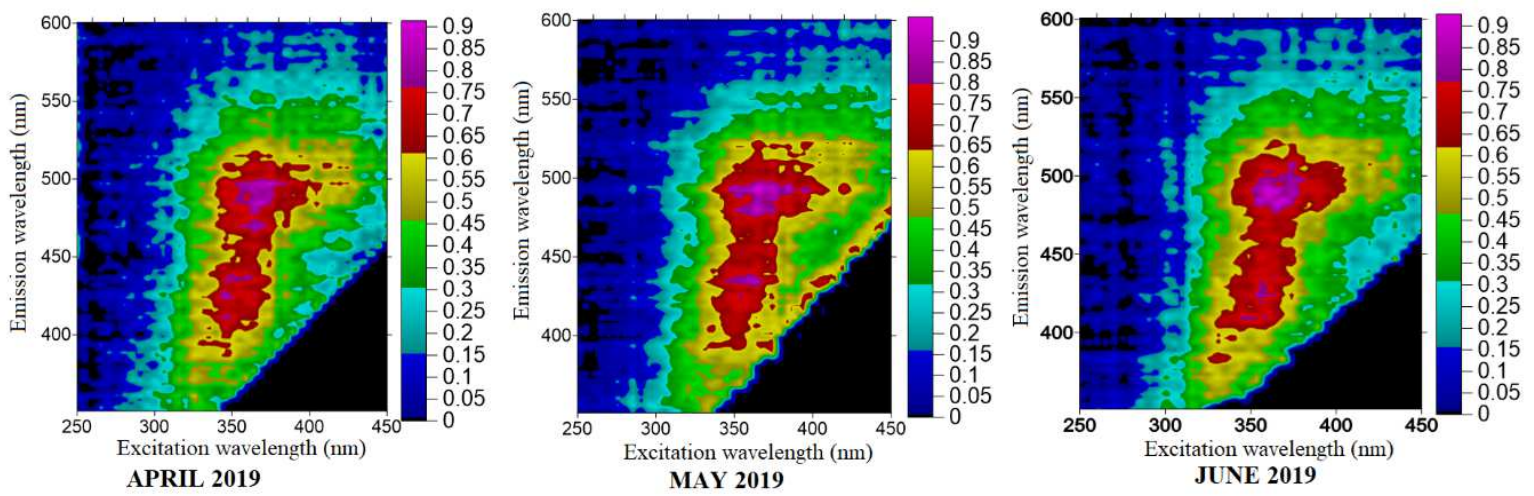

\section{St (4) Valenzuela Station}
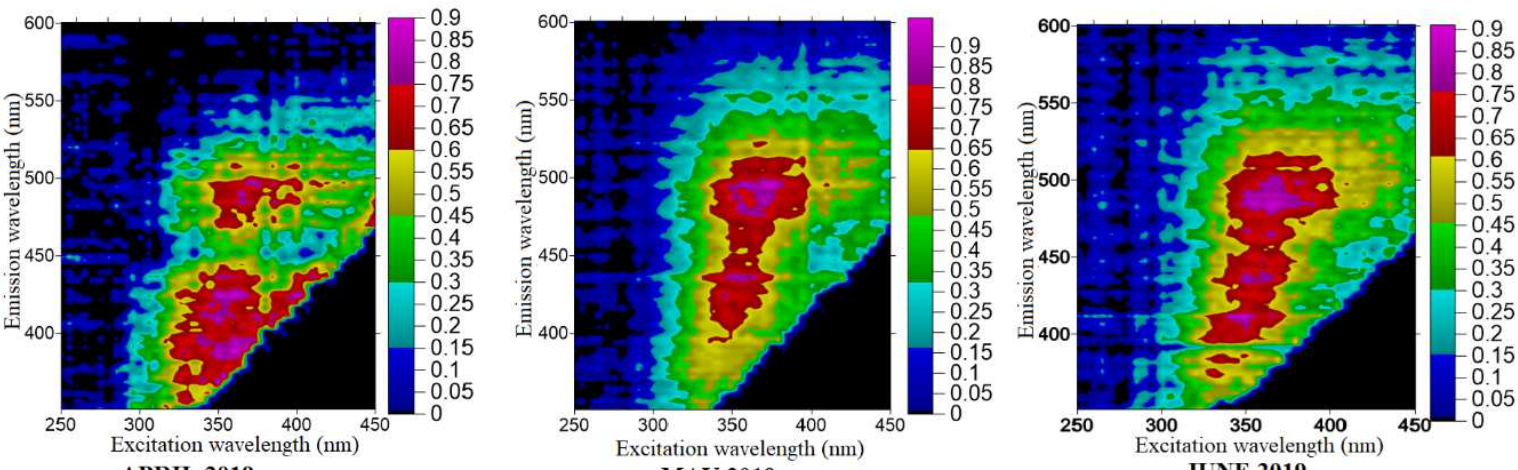

MAY 2019

JUNE 2019

\section{St (7) San Joaquin Station}
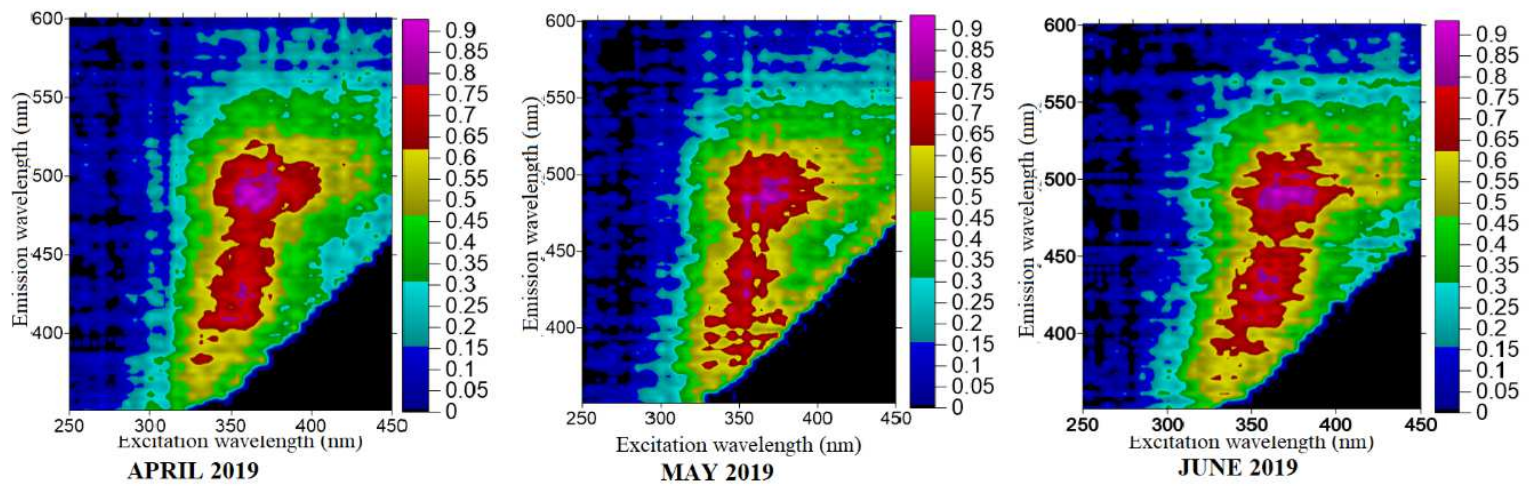

Fig. 5 3D fluorescence excitation-emission matrices of the three sampling sites from April to June 2019. Normalized fluorescence intensities are provided with arbitrary units.

Hence, it provides the highest humification degree from all the sampling stations. The absorbance ratio at wavelengths $253 \mathrm{~nm}$ and $203 \mathrm{~nm}$ were used to identify Trihalomethane formation potential. Trihalomethane formation potential is used to assess the formation of trihalomethanes in urban rivers [44]. It is shown that the trihalomethane formation increased with increasing organic matter and UV absorbance values for all water samples. This suggests that these parameters can be used as predictors of by-products formed with chlorine in the river system [45].

\section{E. Fluorescence EEM plots and analysis}

There are qualitative fluorescence DOM differences observed from the EEMs of the different sampling stations from April to June 2019. Figure 5 shows the image 3D EEM maps of the different sampling stations. The EEMs for each sampling station is unique and infers that the DOM source, 
composition, and its processes vary for each sampling station. The samples' fluorescence spectra were mapped on the same excitation wavelength interval of 5-nm, and emission wavelength interval of $0.5-\mathrm{nm}$. The same fluorescence intensity scale was used for all samples with arbitrary units (a.u.). The fluorescence index (FI) was used to differentiate water samples from microbial and terrestrial sources in this study. The FI values for all samples range from 0.99 to 1.34 , which clearly indicates that terrestrially derived DOM compositions are present.

Peak-T (Tryptophan-like), Peak-A (terrestrial humic substances), and Peak-C (terrestrial, agriculture) were observed in all samples. Protein-like fluorescence such as tryptophan are likely derived from a mixture of dissolved amino acids and other organic materials with similar fluorescence characteristics. However, with its great potential use in ecological applications, there are still limitations on the molecular size and structure of high DOM concentrations which contributes to the detection of fluorescence protein-like signatures. Peaks -A and -C are usually associated with humic substances and vary mainly on its source and molecular size. The peak shifting in excitation wavelength from shorter to longer wavelengths implies an increase of molecule size and aromatic content [13].

The fluorescence measurements observed in all surface water samples mainly vary on the location and season. Figure 6 shows the normalized intensities of the different fluorescence peaks. It is evident that peaks $-\mathrm{A}$ and $-\mathrm{C}$ are largely present in the EEMs for each sampling station during seasonal variation. In St (1) Lawton Station, the month of May 2019 had the highest fluorescence peaks among the threemonth long sampling duration.

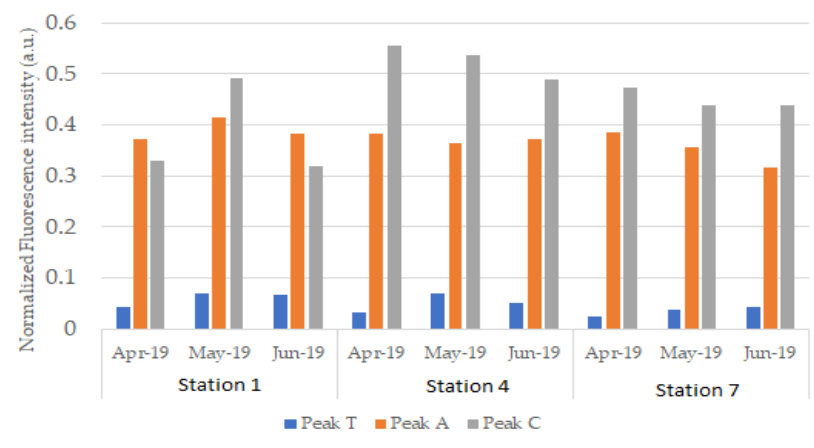

Fig. 6 Normalized fluorescence intensities (a.u.) of the different peaks at the three sampling stations from April to June 2019

Fluorescence EEMs can also be used to determine the impact of sewage effluents discharged from different land-use types near the river system [34]. The ratio of peak-T to peak$\mathrm{C}$ was used to differentiate upstream and downstream water samples. According to [40], peak T fluorescence intensity is strongly correlated with biological oxygen demand in both river systems and sewage effluents. With the observation from the DOM composition's peak-C fluorescence intensity in the three sampling stations, we can correlate peak-T/peak$\mathrm{C}$ ratio as the ratio of $\mathrm{BOD} 5 / \mathrm{DOC}$ ratio terrestrial waters. Figure 7 provides the peak-T/peak-C ratio with seasonal variance and differences in water quality. For April and May 2019, low peak-T/peak-C ratio and high peak-C emission wavelength were observed. This is due to the mixture of marine water from Manila bay as observed by the upstream flow during these months. In this case, the use of peak-T fluorescence cannot sufficiently provide pollutant interpretation due to the contributions of marine biological activity [46]. On the other hand, high peak-T/peak-C ratio but low peak-C emission wavelength was measured in the month of June 2019. As stated, downstream flow was observed this month, showing the impact of Laguna lake in the three sampling stations' water quality.

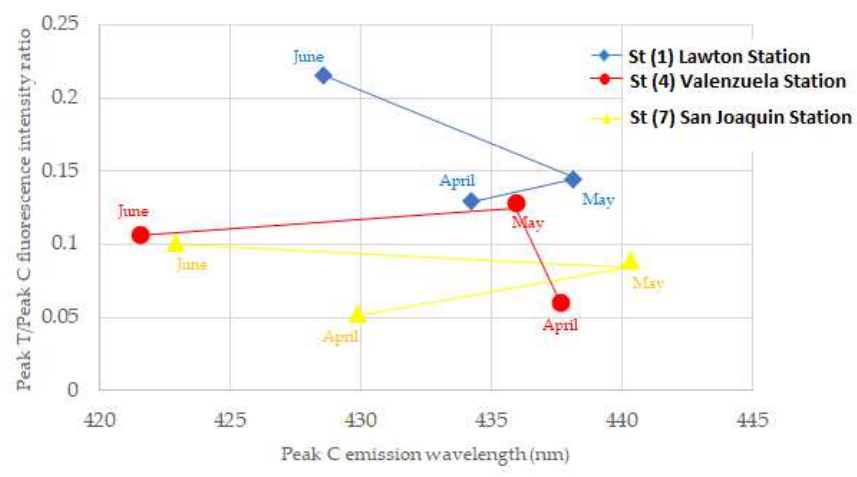

Fig. 7 Normalized fluorescence intensities (a.u.) of the different peaks at the three sampling stations from April to June 2019

The higher intensity of the fluorescence peaks indicated in Fig. 7 confirms the concentration of sewage in all sampling stations. It can be identified from the EEM analysis that the contribution of labile organic matter and presence of humic compounds varies at every station during the three-month sampling period. These combinations are commonly used to evaluate dynamic changes of organic matter in river systems. The EEM fluorescence spectra and identification of regions with higher fluorescence intensity peaks can be used to determine presence of labile organic and humic substances at certain sampling stations, i.e., St (1) Lawton Station and St (4) Valenzuela Station, having different land-use type. These results indicate the direct consequence of urban development and domestic pollution from informal settlers.

\section{F. Correlations between physico-chemical parameters}

Correlations between the absorbance values and ratios with some physico-chemical parameters were observed associated with the dissolved organic matter present in the Pasig river. Table VIII shows the correlation table of the absorbance values and ratios with physico-chemical parameters monitored using three sampling stations during the threemonth sampling period. Several parameters such as dissolved oxygen, total dissolved and suspended solids, total organic carbon, and biological oxygen demand represent a different measure to organic matter and analyze water quality status in a river system. $\mathrm{BOD}_{5}$ is used to evaluate biodegradable organic matter and carbohydrates. However, there are other parameters to identify different organic compounds. 
TABLE VIII

PEARSON's R LiNEAR COEFFICIENT FOR EACH REGRESSION BETWEEN PHYSICO-CHEMICAL PARAMETERS AND ABSORBANCE VALUES (P<0.0001)

\begin{tabular}{|c|c|c|c|c|c|c|c|}
\hline & & & \multicolumn{5}{|c|}{ Absorbance value/ratio } \\
\hline & & & $\begin{array}{c}\text { A280 } \\
\text { (Molecular } \\
\text { size) } \\
\end{array}$ & $\begin{array}{l}\text { A253/203 } \\
\text { (THMFP) }\end{array}$ & $\begin{array}{c}\text { A250/365 } \\
\text { (Molecular } \\
\text { weight) }\end{array}$ & $\begin{array}{c}\text { A254/436 } \\
\text { (DOM } \\
\text { sources) }\end{array}$ & $\begin{array}{c}\text { A340/254 } \\
\text { (TOC/DOC } \\
\text { prediction) }\end{array}$ \\
\hline \multirow{8}{*}{\multicolumn{2}{|c|}{ 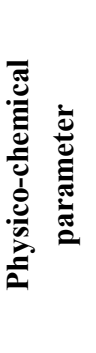 }} & $\mathrm{pH}$ & 0.2668 & -0.1254 & 0.3454 & 0.0020 & -0.5616 \\
\hline & & Temperature $\left({ }^{\circ} \mathrm{C}\right)$ & -0.1569 & 0.2144 & -0.4139 & -0.0451 & 0.0702 \\
\hline & & DO & 0.7085 & 0.2093 & 0.9423 & 0.3833 & 0.0448 \\
\hline & & $\mathrm{EC}$ & -0.0018 & -0.3192 & -0.4087 & -0.0928 & -0.3319 \\
\hline & & TDS & -0.0135 & -0.2445 & -0.4096 & -0.0793 & -0.1006 \\
\hline & & TSS & 0.3252 & 0.1291 & 0.1977 & -0.1226 & 0.6714 \\
\hline & & $\mathrm{TOC}$ & 0.0071 & 0.6196 & 0.1993 & 0.2764 & 0.9678 \\
\hline & & $\mathrm{BOD}_{5}$ & -0.1900 & 0.2353 & -0.4742 & -0.1200 & 0.5639 \\
\hline
\end{tabular}

The relationship between absorbance values and $\mathrm{BOD}_{5}$ evidenced effluents' presence from organic matter in all sampling stations located in Pasig River. Highlighted values showed acceptable correlation between absorbance values and some physico-chemical parameters. The linear relationship between $\mathrm{BOD}_{5}$ and $\mathrm{A} 340 / 254$ (TOC/DOC prediction) collected from three sampling stations is $r=$ $0.5639(\mathrm{n}=10, \mathrm{p}<0.0001)$ showed high correlation. This is highly supported with the linear relations between $\mathrm{BOD}_{5}$ and TOC $(r=0.5383, p<0.0001)$, TOC and A340/254 $(r=0.9678$, $\mathrm{p}<0.0001)$.

TABLE IX

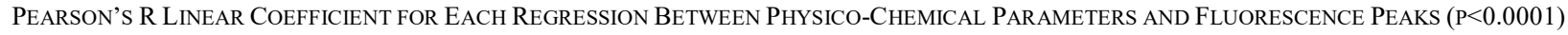

\begin{tabular}{|c|c|c|c|c|}
\hline & & \multicolumn{3}{|c|}{ Fluorescence peak } \\
\hline & & $\begin{array}{c}\text { Peak T } \\
\text { (Trptophan-like) } \\
\end{array}$ & $\begin{array}{c}\text { Peak C } \\
\text { (UV-C humic-like) }\end{array}$ & $\begin{array}{c}\text { Peak A } \\
\text { (UV-A humic-like) }\end{array}$ \\
\hline \multirow{8}{*}{ 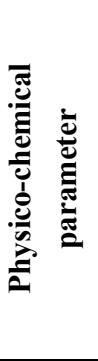 } & $p H$ & -0.4339 & 0.7228 & 0.2080 \\
\hline & Temperature $\left({ }^{\circ} \mathrm{C}\right)$ & -0.0050 & -0.0050 & -0.2663 \\
\hline & $D O$ & -0.5828 & 0.0357 & 0.0576 \\
\hline & $E C$ & 0.2946 & -0.5832 & 0.4447 \\
\hline & $T D S$ & 0.4382 & 0.6601 & 0.4519 \\
\hline & TSS & 0.6260 & 0.2811 & 0.5551 \\
\hline & TOC & 0.7840 & 0.3911 & 0.5027 \\
\hline & $\mathrm{BOD}_{5}$ & 0.5781 & 0.6450 & 0.5113 \\
\hline
\end{tabular}

The presence of labile organic matter can be correlated with $\mathrm{BOD}_{5}$ and fluorescence intensity peaks such as proteinlike (peak T) and humic-like (peak A, peak C) substances. $\mathrm{BOD}_{5}$ values were highly correlated with tryptophan-like substances (peak-T) with $r=0.5781(p<0.0001, n=9)$ and humic-like substances such as peak $\mathrm{C}$ with $\mathrm{r}=0.6450$ $(\mathrm{p}<0.0001, \mathrm{n}=10)$, and peak A with $\mathrm{r}=0.5113(\mathrm{p}<0.0001, \mathrm{n}$ $=10$ ). These tryptophan substances are usually associated with the presence of labile organic matter. However, not all samples may not be directly correlated with $\mathrm{BOD}_{5}$ and other physico-chemical parameters.

The different sources of organic pollution in rivers such as sewage, domestic and industrial effluents, urban and agricultural run-off result in a mixture of compounds with unique absorbance and fluorescence intensities. However, effluents from polluted river samples only showed good correlation between absorbance-fluorescence and $\mathrm{BOD}_{5}$ values while zero to low correlation (below $\mathrm{r}=0.35, \mathrm{p}<0.0001)$ were observed for unpolluted waters. Several factors are affecting the estimated correlation between parameters such as origin and composition of organic matter, biological and physical conditions such as salinity and weather parameters.

With the strong correlations between the absorbance and fluorescence values with $\mathrm{BOD}_{5}$, we can develop a mobile LED fluorescence lidar system that can be used to characterize natural waters or effluents. In-situ lidar monitoring together with physico-chemical testing can provide real-time water quality status.

\section{CONCLUSIONS}

This study provides information on the water quality status of Pasig river from seven sampling stations within the threemonth sampling period. Among seven sampling stations, only three stations namely St (1) Lawton Station, St (4) Valenzuela Station, and St (7) San Joaquin Station were monitored for 
physico-chemical parameters. All DO values were below 2 $\mathrm{mg} / \mathrm{L}$ which are considered hypoxic and did not meet the DENR-DAO standards for "Class C" type. Physico-chemical measurements with the aid of absorbance and fluorescence spectroscopy were used to investigate organic matter contribution in the river system. Parameters such as DO, BOD, TSS, and TDS directly indicated three out of seven sampling stations were polluted and shows significant variance according to the levels of urbanization and organic pollution in Pasig river. However, TOC analyses insignificantly state variance among the stations monitored.

Absorbance and fluorescence spectroscopy set-up were assembled which measures optical properties used in investigating DOM characteristics in river systems. Absorbance values at A254/A436 showed changes in the DOM sources. Respective absorbance values indicated the presence of anthropogenic allochthonous sources such as domestic and urban effluents and humic compounds. 3D fluorescence EEMs from the fluorescence spectroscopy setup provides detailed DOM characteristics compared to absorbance ratios. Strong correlations were observed between Peak T, A, C and BOD, which indicates labile organic matter. The results from the EEMs among the seven sampling stations were highly affected by marine waters and seasonal variance. It also showed that highly urbanized sampling stations were more affected by the presence of Tryptophan-like substances. From these values, significant peaks, and ratios from the fluorescence spectrum such as Tryptophan (Peak -T) and humic substances (Peak -A, -C) can be used to correlate with water quality parameters such as $\mathrm{BOD}_{5}$ and TOC/DOC which can be used in the development of a mobile LED-lidar system.

Fluorescence peaks from 3D EEMs was proven to provide water quality data in polluted rivers. This study confirms the relationship between the spectroscopic values and water quality parameters commonly used in water quality monitoring. This could serve as a breakthrough in water quality monitoring since fluorescence remote sensing delivers spatial and real-time data. The urgency of monitoring river systems can be done rapidly with the help of mobile fluorescence lidar system, which provides quality data for water quality monitoring, and planning and management strategies by government sectors involved.

\section{ACKNOWLEDGMENTS}

J.G.C. acknowledges support from DOST-SEI ASTHRDPNSC scholarship and UP Visayas. We also acknowledge support from CHED Project entitled "Development of a Portable Optical Coherence Tomography System for the Evaluation of Human Skin Analogues". Also, the DLSU CENSER-ARCHERS through EARTH lab for its facilities and support in finishing this project.

\section{REFERENCES}

[1] R.T. Cruz, "The Pasig River, Philippines. In Water Pollution ControlA Guide to the Use of Water Quality Management Principles"; Helmer, R., Hespanhol, I.; 1997, WHO/UNEP, ISBN 0419229108.

[2] L.P. Belo, "Measurement of the Sediment Oxygen Demand of Different Stations of Pasig River Using a Bench-Scale Benthic Respirometer". Master's Thesis, De La Salle University Manila, Philippines, 2008.
[3] Pasig River Rehabilitation Commission. Available online: https://www.adb.org/sites/default/files/project-

document/62108/30308-02-phi-pcr.pdf(accessed on 10 August 2019)

[4] DENR-DAO-06. Water Quality Guidelines and General Effluent Standards of 2016. Available online: https://denr.gov.ph/sectionpolicies/viewrec.php?id=4917\&page=1\&s ort $=$ tl\& filter $=\&$ searchword $=($ accessed on 4 June 2019)

[5] NEDA, List of Priority Programs and projects in the 2017-2022 public investment programs, IN Chapter 20, Ensuring Ecological Integrity, Clean and Healthy Environment accessed http://www.neda.gov.ph/wp-content/uploads/2019/03/Chapter-20Ensuring-Ecological-Integrity-Clean-and-Healthy-Environment.pdf

[6] World bank, North and south Pasig sewerage system project, accessed http://documents.worldbank.org/curated/en/165111468092967035/pd f/667780BR0P11380Official0Use0Only090.pdf.

[7] Philippine Information Agency, PRRC lab studies find Pasig river fishes not suitable for deliberate consumption, https://pia.gov.ph/news/articles/1026049

[8] C. Yoshimura, C. Yamanaka, M. Fuji, S. Leungprasert, M. Tanchuling, "Heavy metals in suspended sediments in rivers flowing through megacities in southeast Asia", ASEAN Engineering Journal Part $C$, vol. 4, no. 1, p. 63, 2014, ISSN 2286-8150.

[9] M. Galvez, J. De Guzman, S. Gueco, J. Camelo, R. Castilla, E. Vallar, "SEM/EDX Analysis of the Roots of Water Hyacinths (Eichornia crassipes) Collected Along Pasig River in Manila, Philippines", ARPN Journal of Agricultural and Biological Science, 2015.

[10] J. Gorme, M. Manaquiz, P. Song, L. Kim, "The water quality of the Pasig river in the city of Manila, Philippines; Current status, management and Future recovery", Environ.Eng.Res, vol. 15, no. 3, p. 173-179, 2010.

[11] K. Okamoto, T. Komoriya, T. Toyama, H. Hirano, T. Garcia, M. Baccay, M. Macasilhig, B. Fortalea, "Purification Experiments on the Pasig River, Philippines Using circulation-type purification system", International Journal of GEOMATE, vol. 16, no. 54, p. 2186-2990, 2019.

[12] X. Guo, J. Jiang, B. Xi, X. He, H. Zhang, Y. Deng, "Study on the spectral and $\mathrm{Cu}$ (II) binding characteristics of DOM leached from soils and lake sediments in the Hetao region", Environ Sci Pollu R, vol. 19, no. 6, p. 2079-2087, 2012.

[13] J. Fellman, E. Hood, R. Spenser, "Fluorescence spectroscopy opens new windows into dissolved organic dynamics in freshwater ecosystems: A review" Limnol. Oceanogr, vol. 55, no. 5, p. 24522462, 2010.

[14] G. Xu-jing, X. Bel-dou, Y. Hui-bin, M. Wen-chao, H. Xiao-song, "The structure and origin of dissolved organic matter studied by UV-Vis spectroscopy and fluorescence spectroscopy in lake and semi-arid region" Water Sci Technol. vol. 63, no. 5, 2011, doi: 10.2166/wst.2011.282.

[15] P. Li, J. Hur, "Utilization of UV-Vis spectroscopy and related data analyses for dissolved organic matter (DOM) studies: A review", Critical Reviews in Environmental Science and Technology 2017, vol. 47, no. 3, p. 131-154, 2017.

[16] L. Santos, A. Pinto, O. Filipe, A. Cunha, E. Santos, A. Almeida, "Insights on the Optical Properties of Estuarine DOM?" Hydrological and Biological Influences. PLOS ONE vol. 11, no. 5, 2016, e0154519.

[17] R. Jaffe, J. Boyer, X. Lu, N. Maie, C. Yang, N. Scully, S. Mock, "Source characterization of dissolved organic matter in a subtropical mangrove-dominated estuary by fluorescence analysis" Marine Chemistry, vol. 84, no. 3-4, p. 195-210, 2004.

[18] E. Tipping, H. Corbishley, J. Koprivnjak, D. Lapwork, M. Miller, C. Vincent, J. Hamilton-Taylor, "Quantification of natural DOM from UV absorption at two wavelengths", Environmental Chemistry, vol. 6, no. 6, p. 472-476, 2009.

[19] O. Zielinski, et al., "Assessing Fluorescent Organic matter in Natural Waters: Towards In Situ Excitation-Emission Spectroscopy", Appl. Sci., vol. 8, no. 12, p. 2685, 2018, https://doi.org/10.3390/app8122685

[20] Y. Zhao et al., "Characterization of CDOM of river waters in China using fluorescence excitation-emission matrix and regional integration techniques", JGR Biogeosciences, vol. 122, no. 8, p. 1940-1953, 2017, https://doi.org/10.1002/2017JG003820

[21] L. Wang, F. Wu, R. Zhang, W. Li, H. Liao, "Characterization of dissolved organic matter fractions from Lake Hongfeng, Southwestern China Plateau", Journal of Environmental Sciences, vol. 21, p. 581588, 2009.

[22] P. Coble, C. Del Castillo, B. Avril, "Distribution and optical properties of CDOM in the Arabian Sea during the 1995 Southwest Monson", Deep-Sea Res Part II, vol. 45, no. 10-11, p. 2195-2223, 1998. 
[23] R. Cory, D. McKnight, "Fluorescence spectroscopy reveals ubiquitous presence of oxidized and reduced quinones in dissolved organic matter", Environ sci Technol, vol. 39, no. 21, p. 8142-81149, 2005.

[24] H. Wilson, M. Xenopoulos, "Effects of agricultural land use on the composition of fluvial dissolved organic matter”, Nat. Geosci., vol. 2, p. 37-41, 2009.

[25] R. Measures, M. Bristow, "The development of a laser fluorosensor for remote environmental probing", Can. Aeronaut. Space. J, p. 421422, 1971.

[26] S. Rogers, T. Websters, W. Livingstone, N. O’Driscoll, “Airborne laser-induced fluorescence (LIF) light detection and ranging (LiDAR) for the quantification of dissolved organic matter in natural waters", Estuaries Coast, vol. 35, p. 959-975, 2012.

[27] C. Zhao, S. Gao, L. Zhou, X. Li, X. Chen, C. Wang, "Dissolved organic matter in urban forestland soil and its interactions with typical heavy metals: a case of Daxing District, Beijing" Environ Sci Pollut Res, vol. 26, p. 2960, 2009.

[28] H. Yu, B. Xi, W. Ma, D. Li, X. He, "Fluorescence spectroscopic properties of dissolved fulvic acids from salined flavo-aquic soils around Wuliangsuhai in Hetao Irrigation District, China”, Soil SciSoc $A m J$ vol. 75, no. 4, p. 1385-1393, 2011.

[29] T. Reyes, J. Crisosto, "Characterization of Dissolved Organic Matter in River Water by Conventional Methods and Direct Sample AnalysisTime of Flight-Mass Spectroscopy", Journal of Chemistry, 2016, Article ID 1537370

[30] J. Belmonte, In Explanatory Note: Pasig River Rehabilitation and Development Authority. Available online: http://www.congress.gov.ph/legisdocs/basic_16/HB05641.pdf (accessed on 3 August 2019).

[31] Google Maps (Pasig River). Available online: https:/www.google.com/maps/place/Pasig+River/@14.5642534,120. $9577051,12 \mathrm{z} / \mathrm{data}=! 3 \mathrm{~m} 1 ! 4 \mathrm{~b} 1 ! 4 \mathrm{~m} 5 ! 3 \mathrm{~m} 4$ ! $1 \mathrm{~s} 0 \times 3397 \mathrm{ca} 1778673307: 0 \times 1$ 4974a3dd95fe625!8m2!3d14.56894!4d121.031757 (accessed on 3 August 2019)

[32] Philippine Geoportal: Metro Manila Land Use 2003. Available online: http://www.geoportal.gov.ph/ (accessed on 12 July 2019)

[33] J. Yisa, T. Jimoh, "Analytical studies on water quality index of river Landzu", American Journal of Applied Sciences, vol. 7, no. 4, p. 453 458, 2010.

[34] R. Hao, K. Cao, G. Zhao, Y. Guan, Y. Zhou, "Ultraviolet absorption spectrum characterization approach for quantitative analysis of dissolved organic contaminants in sewage", Journal of Beijing University of Technology, vol. 32, no. 12, p. 1062-1066, 2006.

[35] P. Coble, "Marine optical biogeochemistry: the chemistry of ocean color", Chemical reviews, vol. 107, p. 402-418, 2007.

[36] K. Murphy, C. Stedon, D. Waite, G. Ruiz, "Distinguishing between terrestrial and autochthonous organic matter sources in marine environments using fluorescence spectroscopy", Marine Chemistry, vol. 108 , p. $40-58,2008$.

[37] C. Stedmon, S. Markager, R. Bro, "Tracing dissolved organic matter in aquatic environments using a new approach to fluorescence spectroscopy", Marine Chemistry, vol. 82, p. 239-254, 2003.

[38] A. Huguet, L. Vacher S. Relexans, S. Saubausse, J. Froidefond, E. Parlanti, "Properties of fluorescent dissolved organic matter in the Gironde Estuary", Org Geochem, vol. 40, no. 6, p. 706-719, 2009.

[39] N. Hudson, A. Baker, D. Ward, D. Reynolds, "Fluorescence analysis of dissolved organic matter in natural, waste and polluted waters - a review", River Res. Appl., vol. 23, no. 6, p. 631-649, 2007.

[40] F. Rholf, R. Sokal, "Statistical Tables",1995., San Francisco, CA: Freeman \& Caomp.

[41] J. Jensen et al., "Pasig river monitoring and modelling- status report 1998", DENR/DANIDA:1999.

[42] P. Westerhoff, D. Anning, "Concentrations and characterisitcs of organic carbon in surface water in Arizona: Influence of urbanization", Journal of Hydrology, vol. 236, no. 3-4, p. 202-222, 2000.

[43] F. Chapelle, P. Bradley, P. McMahon, K. Kaiser, R. Benner, "Dissolved oxygen as an indicator of bioavailable dissolved organic carbon in groundwater", Ground Water, vol. 50, no. 2, p. 230-241, 2012, doi: 10.1111/j.1745-6584.2011.00835.x.

[44] A. Hasan, N. Thacker, J. Bassin, "Trihalomethane potential in treated water supplies in urban metro city", Environmental Monitoring and Assessment, vol. 168, p. 489-497, 2009.

[45] R. Rajamohan, V. Ebenezer, P. Rajesh, V. Venugopala U. Natesan, V. Murugesan, S. Narasimhan, "Trihalomethane formation potential of drinking water sources in a rural location", Advances in Environmental Research, vol. 1, no. 3, p. 181-189, 2012.

[46] P. Naden, G. Old, C. Eliot-Laize, S. Granger, J. Hawkins, R. Bol, P. Haygrth, "Assessment of natural fluorescence as a tracer of diffuse agricultural pollution from slurry spreading on intensely-farmed grasslands" Water Res vol. 44, no. 6, pp. 1701-1712, 2010. 